\section{NÉHÁNY ÉSZREVÉTEL A PEPP SZABÁLYOZÁSRA VONATKOZÓ ELŐTERJESZTÉSRŐL}

Dr. Matits Ágnes (c. egyetemi docens, független nyugdítanácsadó)

\section{ÖSSZEFOGLALÓ}

Ez a hozzászólás a PEPP lehetséges magyarországi hatásairól fogalmaz meg néhány gondolatot. A föbb üzenetek az alábbiakban foglalhatók össze: 1. A magyar nyugdíjpénztárak alapításakor pontosan ugyanazok az indokok hangoztak el, mint a PEPP indoklása kapcsán, nem valamiféle vadonatúj gondolatról van tehát szó. 2. A fejletlenebb tőkepiacú országoknak, így Magyarországnak sem egyértelműen kedvező a PEPP termékek elterjesztése. Nagy valószínűséggel a hazai nyugdíj-megtakarítások egy részének a kiáramlását fogja eredményezni. 3. Nem a nyugdíjcélú megtakarítások adózását kell harmonizálni, hanem elsősorban a nyugdíjalapok hordozhatóságát kellene megoldani. 4. Lehetne a PEPP egy követelményrendszer, így bármely már létező nyugdíjalap is elnyerhetné a PEPP minősítést, ha megfelel a követelményeknek. Ez valódi versenyhelyzetet teremthetne a nyugdíjbiztosítási termékek piacán.

\section{SUMMARY}

This paper gives some thoughts on the possible consequences of the PEPP concepts in Hungary. The messages are as follow: 1 . The concept itself is not really new. The reasons for PEPP listed in the proposal are similar for those what were pointed out in the time of establishment of Hungarian voluntary pension funds 2. The PEPP concept is not really prefers countries with underdeveloped capital markets. Probably the major part of domestic pension savings is going to leave these countries. 3.The harmonisation of taxation of pension savings is not essentials. The most important is to warrant the portability of personal pension funds. 4. It would be desirable to define the requirements for pension products to become a PEPP. All existing pension funds what fulfils these requirements could be classified as a PEPP. It would create a real competitive market for pension products.

Kulcsszavak: nyugdíj-megtakarítások, pán-európai személyes nyugdijtermékek (PEPP) Keywords: pension savings, PEPP, pension funds

JEL: E21, J26

DOI: $10.18530 /$ BK.2018.3.28

http://dx.doi.org/1018530/BK.2018.3.28

\section{A PEPP indokoltságáról}

Az előterjesztés indoklásában bemutatott alapvető érvek (1.-4.) mindegyike elhangzott a magyarországi pénztárak alapításakor is. Az idősödés (ageing) okozta problémák, a nyugdíjas korra biztosítandó megfelelő kiegészítő kereset biztosítása, az egyéni nyugdíjtermékek piacának szükséges bővítése, valamint a többpilléres nyugdíjrendszerektől várható előnyök nem új érvek. A folyó finanszírozású társadalombiztosítási rendszereknek az ismert demográfiai és foglalkoztatottsági jelenségek miatt várható problémái az elmúlt évtizedekben számos vonatkozásban kerültek elő. Így természetesen nem is vitatható, hogy a saját nyugdíjcélú megtakarításokat támogató új termékek mindenképpen hasznosak lehetnek. Biztosan szükség lesz - mint ahogyan ma is szükséges lenne - a társadalombiztosításból várható nyugdíjak kiegészítésére.

Jól érthető az európai tőkepiac integrálására vonatkozó törekvés is (4. és 5. érv a PEPP mellett). Itt azonban már el kell azon gondolkodnunk, hogy a hazai nyugdíjmegtakarítók befektetéseinek kiáramlása nem biztos, hogy a magyarországi gazdaság előnyére szolgálna. Ugyanis nemigen valószínű, hogy az előterjesztésnek megfelelő termékek forgalmazói és a vagyon befektetésére szakosodott intézmények a magyar befektetési lehetőségeket a más - fejlettebb országbeli, következésképpen várhatóan kisebb kockázatú - termékekkel egyenrangú lehetőségként fogják figyelembe venni. Hacsak nem fogunk magasabb hozamokat ígérni, ami viszont azt jelenti, hogy ez nekünk akár sokba is kerülhet. Úgy érzem, hogy a nyugdíjcélú befektetések integrálása számunkra valószínűleg azt jelenti, hogy arányaiban a jelenleginél kevesebb nyugdíjtőke maradna határainkon belül. Ezt persze felfoghatjuk a globalizáció szükségszerű velejárójaként, és biztosan sokan tudnának érveket felsorolni, hogy ez miért lehet jó a fogyasztóknak (biztosítottaknak), de a magyar gazdaság növekedéséhez szükséges tőkeigény kielégítése lehet, hogy problémásabbá válhat.

Végül az érvek harmadik csoportjában (7.-9.) említett költséghatékonyságot tudom a legkevésbé értelmezni. Nem látom be, hogy ez a termék javítana a nyugdíjtermékek piacán hiányolt verseny színvonalán, nem hiszem, hogy a termékek hiánya gátolja a nyugdíjcélú megtakarítások növekedését, vagy, hogy ez a termék jelentősen növelné a transzparenciát. Végül azt sem látom biztosítva, hogy mindezek esetleges bekövetkezése valódi költséghatékonyságot eredményezne. Akár el is hihetjük mindezeket. Ez ugyanis nem akadályozhatja a koncepció megvalósítását.

\section{Az adózási kérdésekről}

Az adózás nemzeti hatáskörbe tartozó téma. A PEPP vonatkozásában kétféle dologról van szó: egyrészt a befizetések adókedvezményéről, másrészt a pénztári jövedelmek (kamatok és szolgáltatások) adóztatásának kérdéseiről. Még ha fel is tételezzük, hogy a jövőben megváltozik a magyar nyugdípénztári befizetők kezdeti időszakban tapasztalt attitűdje, mely szerint a befizetők sokkal inkább adómegtakarítók, mint nyugdíj-megtakarítók vol- 
tak, akkor is el kellene várnunk, hogy a magyar piacon a nyugdíjbiztosítási termékekkel kapcsolatosan létező adókedvezmények a PEPP befizetésekre is vonatkozzanak. E nélkül valószínűleg nehezen szervezhető ezeknek a termékeknek az elterjesztése. Pedig az a kérdés, hogy az egyes tagországok hogyan kezelik az ezekbe történő befizetések adózását, akár független is lehetne a PEPP bevezetésétől. Ennek ugyanis nincsen köze közvetlenül a nyugdíjcélú megtakarításokhoz. Legfeljebb azok ösztönzéséhez van köze, vagy éppen az adott állam tőkeéhségének csillapításához. Nem biztos azonban, hogy reális elvárás, hogy egy külföldön kezelt nyugdíjalapba történő befizetés ugyanolyan adókedvezményeket élvezzen, mint egy hazai alapba történő befizetés.

Nem reális elvárás, hogy egy külföldön kezelt nyugdíjalapba

történő befizetés ugyanolyan adókedvezményeket élvezzen, mint egy hazai alapba történő befizetés.

Természetesen külön megfontolást igényel a nyugdíjalapokból szerzett jövedelmek (kamat és szolgáltatások) adóztatása is. Valószínűleg itt az lehet a követendő elv, hogy a nyugdíjalapokból jövedelmet szerző pénztártag melyik országban adózik. İgy akár különböző adózási rendszerekben is létezhetne ugyanaz a PEPP. Ez persze még sok vita alapja lehet, így végül érdeklődéssel várom az erre vonatkozó konkrét ajánlásokat. Meggyőződésem azonban, hogy ez biztosan megoldható.

\section{Milyen szolgáltatások várhatók?}

Már a magyar tapasztalatok is azt mutatják, hogy ha egy szolgáltató csak arra van kötelezve, hogy a felsorolt lehetséges szolgáltatások (életjáradék, egyösszegű kifizetés, ütemezett kifizetések vagy ezek kombinációja) közül legalább egyet kell a megtakarítóknak biztosítania, akkor nagy valószínűséggel nem fog életjáradék szolgáltatásokat kínálni. Így a PEPP bevezetésétől nem remélhetjük, hogy elősegíti a leginkább nyugdíjszerű szolgáltatások elterjedését. Minőségi előrelépést - és egyúttal a magyar önkéntes nyugdíjpénztárakhoz képest némi előnyt - csak az jelenthetne, ha minden esetben kötelező lenne, hogy a PEPP biztosan kínáljon életjáradék-jellegű szolgáltatást.

\section{Ki lehet a szolgáltató?}

Az előterjesztés kapcsán mindenekelőtt azon kezdtem el gondolkodni, hogy miben is tér el ez a most tárgyalt termék a már létezőktől? Valóban új termékről van-e szó, vagy pedig egy olyan jogosultságról, amelyet bizonyos termékeknek kívánnak megadni? De akkor miért ne lehetne megfordítani a gondolkodást? Az EU kompetenciája lehetne kidolgozni azt a kritériumrendszert, amelynek nyomán minden olyan, bármely tagállamban forgalmazott nyugdíjtermék megkaphatná a PEPP minősítést, amely ezeknek a kritériumoknak megfelel. Mindez számomra azt üzeni, hogy a fó kérdés a nyugdijtőke határokon keresztüli hordozhatóságának szabályozása lehetne, nem pedig egy határokon átnyúlóan értékesítendő termék kidolgozása, illetve annak a nemzeti adórendszerekkel való összehangolása, amennyiben tényleg nemzeti hatáskörben kívánják tartani az adó- és nyugdíjügyeket. Azokban a tagországokban, ahol valóban a termékek hiánya akadályozza a nyugdíjcélú egyéni megtakarítások piacának bővítését, természetesen ezek a termékek is hasznosak lehetnének. Magyarországon azonban nem ez a helyzet. Nekünk vannak jó termékeink, amelyek közül több is - a legföbb tulajdonságait tekintve - akár PEPP-nek is lehetne minősítve. Sajnos nem látom, hogy ez a fajta megközelítés, azaz a létező termékek PEPPpé való „átminősítése” ahelyett, hogy új, kizárólagosan PEPP-nek nevezett terméket hoznának létre, benne van-e az elöterjesztésben, vagy sem. Ráadásul a terméknek az előterjesztésben felsorolt lehetséges forgalmazói („vagyonkezelők(!), biztosítók, bankok, munkáltatói nyugdíjalapok (IORP)) és néhány befektetési cég" között nem szerepelnek a mi intézményeink, nevezetesen a nyugdíjpénztárak. Vagyis a PEPP bevezetése egyértelmüen a magyar önkéntes pénztári rendszer kárára valósulhatna meg!

\section{IRODALOMJEGYZÉK}

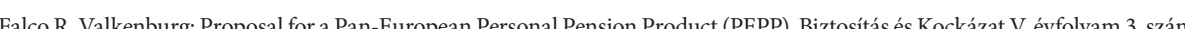

